\title{
DAMPAK PELAKSANAAN MODEL MATEMATIKA REALISTIS PADA PENINGKATAN KEMAMPUAN PENALARAN DEDUKTIF SISWA SEKOLAH MENENGAH DI PARUNG KABUPATEN - KABUPATEN BOGOR
}

\author{
Yumiati (yumi@ut.ac.id) \\ Tarhadi (tarhadi@ut.ac.id) \\ Fakultas Keguruan dan IImu Pendidikan Universitas Terbuka
}

\begin{abstract}
This study attemps to determine impact of the implementation of Realistic Mathematics Education (RME) model on the improvement of deductive reasoning ability, and to describe the perceptions of teachers and students of secondary schools toward the RME model. A quasi-experiment with pretest-postest non-equivalent group as research design was employed into 2 groups of research subject: the experimental group and the control group and each was treated under RME and conventional teaching model. A number of 44 students of SMPN1 Parung and 20 students of SMP Islam Terpadu Jabon Mekar in Parung District were chosen as research subjects. Quantitative data obtained through questionnaires and written tests were analyzed using Student-t test. While qualitative information gathered through responses to personal interview and observations was analyzed using qualitativenaturalistics method. Findings reveals that learning mathematics using the RME model impacts on increasing students' deductive learning ability in both schools with amount of increase is 30.7 for SMP Islam Terpadu and 44.8 for SMPN1 Parung. RME model also impacts on developing students' positive attitude of students toward mathematics as seen in the number of students who liked mathematics lesson, that is 100\% for SMP Islam Terpadu and 97\% SMPN 1 Parung. The perceptions of teachers and students in both schools toward the RME Model are positive. Application of learning mathematics using PMR model becomes more enjoyable and students become more active.
\end{abstract}

Keywords: deductive reasoning ability, mathematics Realistic Model, perception, secondary school

Matematika merupakan pengetahuan abstrak yang dibangun melalui proses penalaran deduktif. Kekuatan matematika terletak pada aspek penalaran. Setiap pernyataan dalam matematika muncul dari pernyataan sebelumnya secara logis dan sistematis. Tidak terdapat kontradiksi pernyataan-pernyataan dalam matematika.Oleh karena itu, kemampuan penalaran merupakan salah satu kemampuan yang ingin dicapai dalam semua jenjang pendidikan matematika di sekolah, termasuk Sekolah Menengah Pertama/SMP (Permen Diknas No. 22/2006). Kemampuan penalaran adalah kemampuan siswa dalam mengambil suatu kesimpulan berdasarkan data yang ada. Kemampuan menalar membentuk siswa untuk berpikir logis, kritis, dan sistematis. Matematika dibangun melalui penalaran deduktif (Soejadi, 2000). Meskipun dalam matematika sekolah untuk membangun pengetahuan siswa diawali dengan penalaran induktif, namun pada akhirnya siswa tetap diharapkan mampu bernalar secara deduktif. Penalaran deduktif adalah cara berpikir untuk 
menarik suatu kesimpulan dari pernyataan yang bersifat umum menuju pernyataan yang bersifat khusus (Suriasumantri, 1998).

Salah satu indikator yang menunjukkan ketercapaian dalam pencapaian tujuan pembelajaran matematika (kemampuan menalar) adalah kemampuan siswa dalam memecahkan masalah (soal), baik masalah dalam kehidupan sehari-hari maupun masalah (soal) dalam matematika. Seperti dalam menyelesaikan soal-soal Ujian Akhir Nasional/Ujian Nasional.

Secara nasional pencapaian Hasil Ujian Akhir Nasional (UAN) mata pelajaran matematika pada jenjang sekolah menengah pertama maupun atas dari tahun ke tahun rendah. Rata-rata Nilai Ebtanas Murni (NEM) mata pelajaran matematika SLTP di seluruh Indonesia dari tahun 1990 hingga tahun 2000 pada umumnya berada di bawah nilai 5,0 dari skala 0 sampai dengan 10 (Hamzah, 2003). Hasil studi Suryanto dan Somerset terhadap 16 SLTP pada beberapa provinsi di Indonesia juga menemukan bahwa hasil tes mata pelajaran matematika siswa sangat rendah (Zulkardi, 2003). Kemampuan matematika siswa yang rendah menunjukkan kemampuan penalaran deduktif siswa juga rendah.

Rendahnya kemampuan penalaran deduktif siswa dapat disebabkan oleh beberapa faktor. Pertama dan terutama adalah pada pembelajaran matematika itu sendiri. Pembelajaran matematika yang dilakukan saat ini didominasi oleh kegiatan guru. Pembelajaran berlangsung cenderung satu arah, dari guru ke siswa. Guru menjelaskan pengertian konsep dalam matematika, memberikan contoh konsep, memberikan soal latihan, dan menyampaikan rangkuman. Sementara itu, siswa cenderung bersifat pasif dengan mendengar penjelasan guru dan mencatat tulisan guru yang terdapat pada papan tulis. Hal tersebut sesuai dengan pendapat Marpaung (2004) bahwa pembelajaran matematika di sekolah pada umumnya masih bersifat menjejalkan pengetahuan ke pikiran siswa, dan pendapat Pannen (2004) bahwa penyampaian pelajaran matematika kepada siswa lebih menekankan pada pencapaian kurikulum dan penyampaian materi secara tekstual semata daripada mengembangkan kemampuan belajar dan membangun kreativitas serta logika berfikir siswa.

Untuk dapat mencapai tujuan pembelajaran matematika, perlu dilakukan perubahan dalam pembelajaran matematika di SMP. Dari pembelajaran yang berorientasi pada guru (teacher center) menjadi pembelajaran yang berorientasi pada siswa (student center). Pembelajaran yang berorientasi pada siswa didasari atas teori konstruktivisme. Teori ini menjelaskan bahwa siswa mengkonstruksi sendiri pengetahuan yang diperolehnya. Salah satu model pembelajaran yang didasari oleh paradigma konstruktivis adalah model pembelajaran matematika realistik (PMR). Model pembelajaran ini memandang bahwa matematika sebagai aktivitas manusia. PMR didasari atas lima karakteristik dan tiga prinsip. Kelima karakteristik tersebut adalah: 1. menggunakan konteks, 2. menggunakan model, 3. menggunakan kontribusi dari hasil siswa sendiri, 4. interaktivitas dalam proses pembelajaran, dan 5. terintegrasi dengan berbagai topik. Sementara itu, tiga prinsip PMR adalah: 1. penemuan kembali dan progresif matematika, 2. fenomena pendidikan, dan 3. pengembangan model oleh siswa sendiri (De Lange, 1987; Gravemeijer, 1994). Melalui karakteristik dan prinsip tersebut diduga PMR dapat menumbuhkan kemampuan penalaran siswa. Beberapa hasil penelitian menunjukkan bahwa PMR dapat meningkatkan hasil belajar siswa dan menumbuhkan sikap positif siswa terhadap matematika. Hasil penelitian Haji (2006) menunjukkan PMR mampu meningkatkan kemampuan pemecahan masalah siswa. Sedangkan Turmudi (2000) mengungkapkan bahwa pendekatan realistik dalam pembelajaran matematika dapat mengubah minat siswa menjadi bersikap positif terhadap matematika. Selanjutnya, yang menjadi pertanyaan 
adalah bagaimana dampak model PMR terhadap peningkatan kemampuan penalaran deduktif siswa SMP dan bagaimana persepsi guru dan siswa terhadap model PMR.

Penelitian ini bertujuan untuk mengidentifikasi dampak pelaksanaan model Pembelajaran Matematika Realistik (PMR) terhadap peningkatan kemampuan penalaran deduktif dan menjelaskan persepsi guru dan siswa terhadap model pembelajaran.

\section{METODOLOGI}

Penelitian dilaksanakan terhadap siswa SMP di wilayah Kecamatan Parung, yaitu siswa SMP Negeri 1 Parung dan SMP Islam Terpadu (SMPIT) Jabon Mekar Parung Bogor sebagai subyek penelitian. Perlakuan (implementasi) model PMR dilaksanakan terhadap satu kelas eksperimen dan satu kelas kontrol di setiap sekolah. Melalui cara ini, maka penelitian kuasi eksperimen (eksperimen semu) dilakukan untuk mencapai tujuan tersebut. Kelas eksperimen merupakan kelas yang diajarkan dengan menggunakan model PMR dan kelas kontrol diajarkan dengan menggunakan model pembelajaran biasa. digunakan terdiri atas kuesioner, lembar observasi, tes tertulis, dan pedoman wawancara.

\section{HASIL DAN PEMBAHASAN}

\section{Pelaksanaan Pembelajaran Matematika Realistik}

Pelaksanaan pembelajaran di kelas dilakukan pada semester 4 (empat), bulan April - Mei 2009. Topik yang dibahas dan jumlah jam pelajaran untuk setiap sekolah seperti tertera pada tabel berikut.

Tabel 1. Topik dan Jumlah Jam Pelajaran Pelaksanaan Pembelajaran dengan Model PMR

\begin{tabular}{clc}
\hline \multicolumn{1}{c}{ Sekolah } & Topik & Jumlah Pertemuan \\
\hline SMPIT Jabon Mekar & Garis-garis Segitiga & $6 \times 2$ jam \\
SMPN 1 Parung & Prisma & $5 \times 2$ jam \\
\hline
\end{tabular}

Hasil pengamatan pada pelaksanaan pembelajaran di kedua sekolah dan hasil wawancara dengan lima orang siswa dari masing-masing sekolah menyebutkan bahwa (i) siswa masih belum terbiasa belajar secara berkelompok, (ii) Siswa masih mengharapkan duduk manis mendengarkan penjelasan guru, guru mencatat lalu siswa menulis, (iii) pembelajaran masih berpusat pada guru, dan (iv) untuk melaksanakan kerja kelompok, siswa masih memerlukan bimbingan.

\section{Persepsi Siswa tentang Pembelajaran Matematika Realistik}

Data dan informasi tentan persepsi siswa tentang Pembelajaran Matematika Realistik diperoleh setelah pelaksanakan pembelajaran model PMR. Dalam tahapan ini, siswa kelas eksperimen diberi kuesioner 2 (kuesioner siswa survey 2) yang berisi informasi tentang pengalaman yang diperoleh siswa setelah mengikuti pelajaran, persepsi siswa tentang diskusi dan kegiatan lain di dalam kelas, apakah siswa menyukainya, manfaat yang diperoleh setelah mengikuti pelajaran, apakah siswa lebih mudah memahami materi, dan komentar siswa tentang pelajaran yang sudah dilaksanakan.

Pengalaman yang diperoleh siswa setelah mengikuti pelajaran

Setelah mengikuti pelajaran selama lebih kurang 3 (empat) minggu, siswa yang memberikan komentar positif tentang pengalaman yang diperoleh sebanyak 100\% untuk SMPIT Jabon Mekar, 
dan 97\% untuk SMPN 1 Parung. Komentar positif siswa adalah: kerjasama, aktif, mendefinisikan sendiri, siswa mulai tertarik untuk mempelajari lebih dalam materi matematika, menyenangkan, matematika yang tadinya rumit menjadi tidak sulit, sekarang agak menyukai matematika, belajar matematika jadi lebih mudah untuk dipelajari, dan yang tadinya malas untuk belajar matematika karena memakai rumus atau cara yang cukup sulit menjadi lebih mudah, ternyata matematika cukup menyenangkan, lebih mengerti dalam pelajaran matematika. Sedangkan siswa yang berkomentar negatif adalah: susah megerjakan soal individu karena waktunya terlalu cepat.

Persepsi siswa tentang diskusi dan kegiatan lain di dalam kelas

Gambar 1 menunjukkan persepsi siswa tentang diskusi dan kegiatan lain di dalam kelas. Sebagian besar siswa (88\% SMPIT Jabon Mekar dan 97\% SMPN 1 Parung) dapat mengikuti diskusi dan kegiatan di kelas.

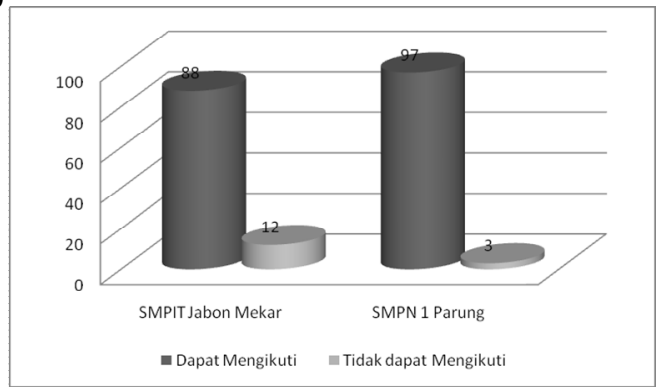

Gambar 1. Banyak Siswa yang Dapat Megikuti Kegiatan atau Diskusi Lain

Alasan mereka mengatakan dapat mengikuti atau tidak dapat mengikuti diskusi dan kegiatan lain di dalam kelas untuk kedua sekolah tersebut adalah sebagai berikut.

Tabel 2. Alasan Siswa dapat Mengikuti Kegiatan dan Diskusi Lain

\begin{tabular}{|c|c|c|}
\hline & \multicolumn{2}{|l|}{ Alasan } \\
\hline & Dapat Mengikuti & $\begin{array}{c}\text { Tidak dapat } \\
\text { Mengikuti }\end{array}$ \\
\hline $\begin{array}{l}\text { SMPIT } \\
\text { Jabon Mekar }\end{array}$ & $\begin{array}{l}\text { - Kegiatan yang diberikan mulanya dikerjakan secara kelompok } \\
\text { sampai dipahami. Setelah paham, masing-masing anak dikasih } \\
\text { selembar kertas untuk mengerjakan soal per individu } \\
\text { - Bisa lebih percaya diri untuk mengeluarkan pendapat kepada } \\
\text { teman, dari pada berdiskusi dengan guru } \\
\text { - Cukup bagus } \\
\text { - Lebih mengerti, lebih enak belajar kelompok, dan gampang } \\
\text { mengingat rumus } \\
\text { - Dapat membantu teman supaya bisa dan cepat mengerti } \\
\text { - Menyenangkan } \\
\text { - Dapat bertukar pikiran dengan teman-teman tentang materi } \\
\text { - yang dipelajari } \\
\text { - Diskusi lebih memudahkan untuk mengerjakan tugas } \\
\text { - Penjelasan cukup jelas }\end{array}$ & $\begin{array}{l}\text { - Lupa rumusnya } \\
\text { karena tidak dicatat } \\
\text { - Jadi sering ngobrol } \\
\text { dengan teman, tapi } \\
\text { mudah dimengerti }\end{array}$ \\
\hline
\end{tabular}


Tabel 2. Lanjutan

\begin{tabular}{|c|c|c|}
\hline & \multicolumn{2}{|l|}{ Alasan } \\
\hline & Dapat Mengikuti & $\begin{array}{c}\text { Tidak dapat } \\
\text { Mengikuti }\end{array}$ \\
\hline $\begin{array}{l}\text { SMPN } 1 \\
\text { Parung }\end{array}$ & $\begin{array}{l}\text { - Lebih mengerti dan belajar tidak bosan } \\
\text { - Bisa bertukar pendapat dengan yang lain untuk menjawab soal } \\
\text { yang diberikan } \\
\text { - Bisa bertanya ke teman/ke guru kalau kita tidak tahu } \\
\text { - Jika berdiskusi dalam kelompok akan sama-sama mengerti, } \\
\text { dan dapat mengeluarkan pikiran masing-masing, lalu } \\
\text { menyatukan pikiran-pikiran yang berbeda-beda dalam satu } \\
\text { kelompok. Sedangkan jika tidak ada diskusi (hanya materi saja } \\
\text { yang diberikan) tidak semua anak mengerti } \\
\text { - Mudah menyelesaikan soal/masalah yang diberikan } \\
\text { - Mudah untuk berkkonsentrasi } \\
\text { - Belajarnya tidak hanya menghafal, dan belajarnya dengan } \\
\text { memberikan praktek dan kelompok } \\
\text { - Mengasyikkan dan menyenangkan } \\
\text { - Metodenya berbeda }\end{array}$ & $\begin{array}{l}\text { Kelompok diskusinya } \\
\text { dipilih, lebih baik } \\
\text { murid yang memilih } \\
\text { sendiri kelompok } \\
\text { diskuinya }\end{array}$ \\
\hline
\end{tabular}

Memperhatikan alasan-alasan tersebut, maka sebagian besar siswa dapat mengikuti diskusi dan kegiatan di kelas dikarenakan mereka aktif dan ada interaksi antar mereka. Sedangkan siswa yang tidak dapat mengikuti diskusi dan kegiatan lain, berdasarkan alasan yang dikemukakan kemungkinan disebabkan mereka terbiasa duduk dengan manis mendengarkan penjelasan guru dan mencatatnya, sehingga mereka merasa kesulitan menghafal rumus jika tidak diberikan catatan oleh gurunya, padahal semua rumus sudah tersedia di dalam buku pegangan mereka.

Apakah siswa menyukainya?

Perbandingan antara siswa yang menyukai pelajaran dan yang tidak menyukai terlihat pada Gambar 2.

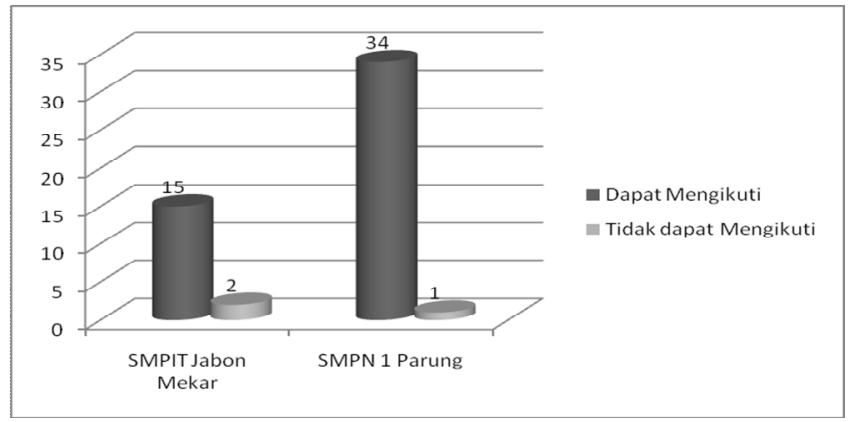

Gambar 2. Banyak Siswa yang Menyukai Pelajaran

Terjadi perubahan sikap siswa terhadap pelajaran matematika, pada pra pembelajaran lebih banyak siswa yang tidak menyukai matematika (SMPIT Jabon Mekar: 21,7\% menyukai dan 65,2\% tidak menyukai matematika; di SMPN 1 Parung: 27,5\% menyukai dan 42,5\% tidak menyukai matematika), sedangkan setelah pembelajaran terlihat jauh lebih banyak siswa yang menyukai pelajaran 
matematika. Beberapa siswa yang tadinya tidak menyukai matematika menjadi menyukai matematika Hal tersebut diperoleh dari kutipan siswa yang mereka kemukakan dalam kuesioner dan wawancara.

\section{Manfaat yang diperoleh setelah mengikuti pelajaran}

Dalam kuesioner siswa survey 2, siswa diminta juga untuk mengungkapkan manfaat apa yang diperoleh setelah mengikuti pembelajaran. Diperoleh data $100 \%$ siswa di kedua sekolah mendapatkan manfaat yang positif dari pembelajaran yang telah dilakukan, yaitu siswa (i) dapat memahami materi dengan pandangan yang berbeda, (ii) dapat belajar bekerja sama dengan baik dan teliti, dan (iii) dapat belajar dengan lebih mudah dan menyenangkan, (iv) dapat mengingat dengan cepat, berlatih mengungkapkan pendapat, dan berlatih memahami rumus, (v) lebih mengerti materi yang sebelumnya sulit dimengerti, dan (vi) menjadi lebih semangat untuk belajar matematika. Selain itu, bagi siswa pelajaran matematika yang diberikan menyenangkan dan soal-soal yang diberikan mudah dipahami dan tidak terlalu rumit. Demikian pula, ternyata matematika tidak hanya tergantung dari soal-soal latihan atau ulangan tetapi melalui diskusi dapat saling bertukar pikiran dan memberi motivasi.

Apakah siswa lebih mudah memahami materi?

Hasil analisis data menunjukkan bahwa sebagian besar siswa menyatakan bahwa mereka mudah memahami materi setelah mendapat pembelajaran dengan PMR (Gambar 3).

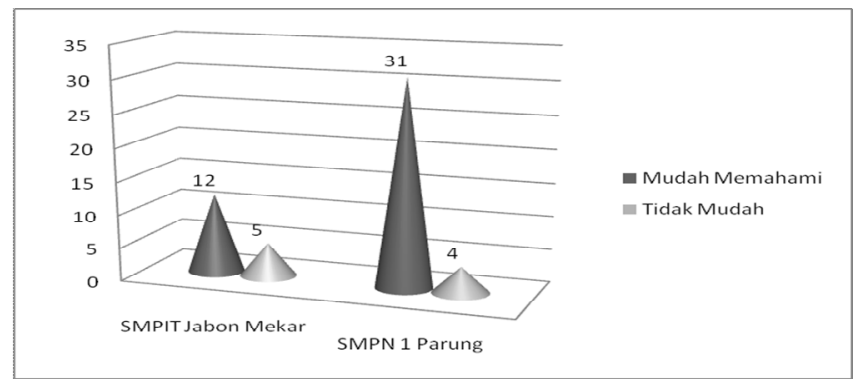

Gambar 3. Data Pemahaman Materi Siswa

Alasan mengapa mereka lebih mudah memahami hampir sama dengan alasan-alasan mengapa mereka menyukai. Sedangkan siswa yang tidak mudah memahami materi sebagian besar mengatakan karena memang mereka tidak menyukai matematika dan ada juga yang mengatakan tidak diterangkan secara detail, hal ini mungkin disebabkan mereka terbiasa menerima penjelasan guru.

Komentar siswa tentang pelajaran yang sudah dilaksanakan

Hasil analisis data tentang komentar siswa terhadap pelajaran yang dilaksanakan menunjukkan bahwa 81 persen siswa memberikan komentar positif dan 19 persen memberikan komentar negatif seperti pada Tabel 3. 
Table 3. Komentar siswa tentang pelajaran yang sudah dilaksanakan

\begin{tabular}{|c|c|}
\hline Positif (81\%) & Negative (19\%) \\
\hline 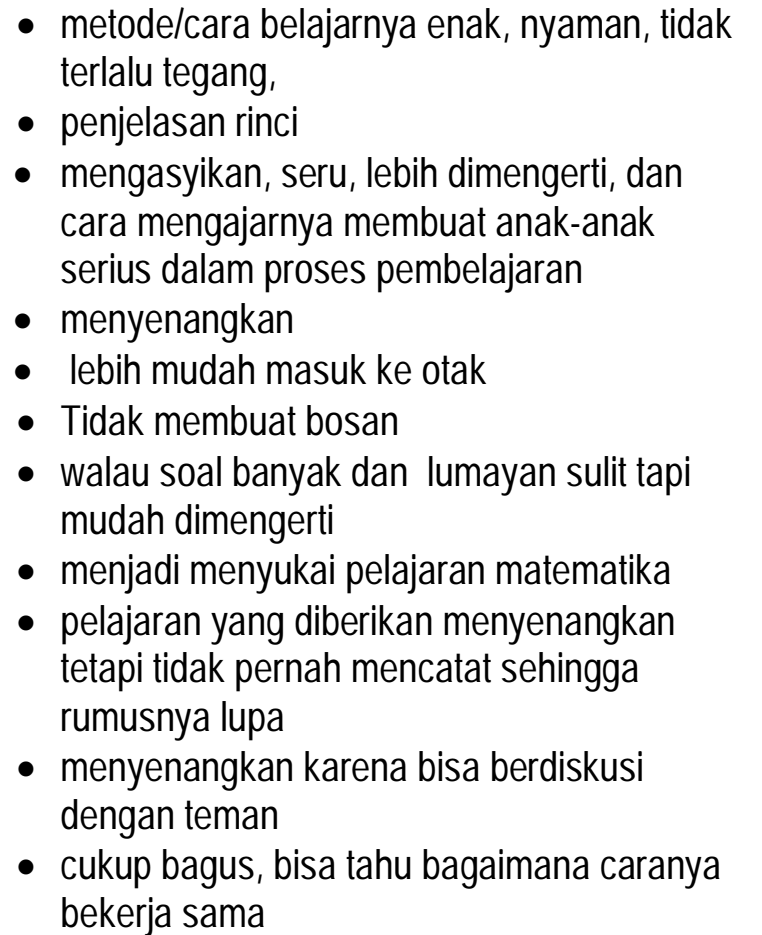 & $\begin{array}{l}\text { - guru memberikan catatan agar siswa tidak } \\
\text { - } \text { penpangelasan kupa } \\
\text { - } \text { waktu yang diberikan untuk mengerjakan } \\
\text { soal individu jangan cepat-cepat } \\
\text { - belajar dengan praktek cukup bagus, tetapi } \\
\text { apabila terlalu sering jadi tidak terlalu } \\
\text { menyenangkan. }\end{array}$ \\
\hline
\end{tabular}

\section{Persepsi Guru tentang Pembelajaran Matematika Realistik}

Persepsi Guru tentang Pembelajaran Matematika Realistik berdasarkan pengisian kuesioner dan hasil wawancara dengan guru yang mengajar matematika di kedua sekolah menyebutkan bahwa hambatan-hambatan yang dihadapi mereka dalam mengajar matematika adalah buku untuk siswa, media atau alat peraga yang tidak memadai dan terbatas, serta minat anak yang kurang. Guru SMPIT Jabon Mekar mengatakan tidak pernah mendengar PMR, sedangkan guru SMPN 1 Parung mengetahui tentang PMR dan menurutnya PMR adalah proses pengajaran dengan alat peraga atau alam sekitar.

Menurut para guru, tidak semua materi dapat diterapkan dengan PMR. Materi yang cocok menggunakan model PMR adalah bangun datar, bangun ruang, aritmetika sosial, dengan alasan materi-materi tersebut alat peraganya mudah dibuat dan siswa dapat praktek langsung. Menurut guru yang lain untuk materi kelas dua ada beberapa yang sulit diterapkan model PMR yaitu materi logaritma, karena guru tersebut merasa kesulitan mendapatkan masalah realistiknya. Kelebihan model PMR menurut guru adalah: pembelajaran menjadi lebih menarik; terjadi diskusi antar siswa; siswa terbiasa bekerja sama; siswa akan lebih tertantang untuk menggali matematika; siswa tidak mengandalkan guru; dan menjawab pertanyaan siswa tentang penerapan matematika dalam kehidupan sehari-hari. Sementara kendala yang dihadapi guru dalam penerapan model PMR adalah: pembuatan alat peraga; persiapan guru harus lebih matang; memerlukan waktu yang cukup banyak baik persiapan maupun pelaksanaan; bertolak belakang dengan ujian nasional (UN) yang lebih menuntut hasil; akan kesulitan diterapkan pada kelas dengan kemampuan kurang; serta tidak semua materi dapat diterapkan model PMR. 


\section{Kemampuan Penalaran Deduktif Siswa}

Kemampuan penalaran deduktif siswa diukur melalui tes. Tes diberikan kepada siswa sebelum (pretes) dan sesudah (postes) pembelajaran dengan menggunakan model PMR. Tes tersebut berisi soal yang penyelesaiannya menggunakan penalaran deduktif. Penalaran deduktif merupakan suatu proses berpikir dari hal-hal yang umum menuju hal-hal yang khusus. Tes untuk mengukur kemampuan penalaran deduktif berbentuk campuran pilihan ganda dan tes uraian yang terdiri dari 10 butir soal untuk materi segitiga (SMPIT Jabon Mekar) dan 7 butir soal untuk materi prisma (SMPN 1 Parung).

Berdasarkan hasil olahan data dengan menggunakan software MINITAB V.13. menunjukkan bahwa taraf signifikansi kurang dari 5\% untuk kemampuan penalaran deduktif di kedua sekolah, yang berarti menolak $\mathrm{H}_{0}$ atau terdapat perbedaan yang signifikan rata-rata hasil belajar tentang kemampuan penalaran deduktif antara kelas eksperimen dan kelas kontrol. Perbedaan tersebut ditunjukkan juga dengan nilai rata-rata hasil belajar pada kedua kelompok di kedua sekolah seperti terlihat pada Gambar 4.

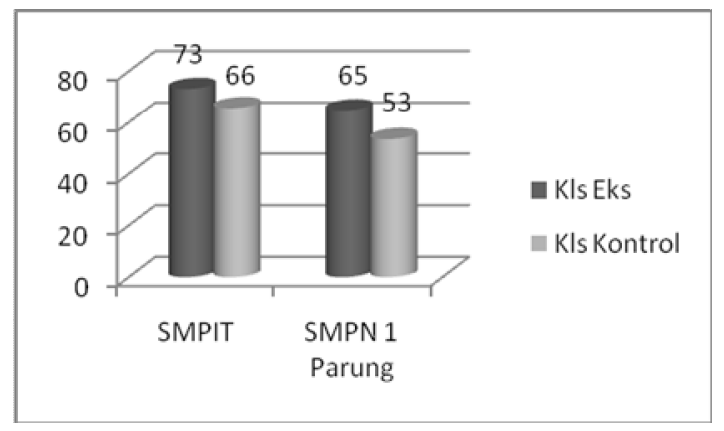

Gambar 4. Rata-rata hasil belajar

Dari Gambar 4 di atas terlihat bahwa rata-rata hasil belajar tentang kemampuan penalaran deduktif siswa kelas eksperimen di kedua lokasi penelitian lebih tinggi dari rata-rata hasil belajar kelas kontrol pada kedua sekolah. Hal ini berarti bahwa kemampuan penalaran deduktif siswa yang diajar dengan menggunakan model PMR lebih tinggi dari pada siswa yang diajar dengan cara biasa. Hasil tersebut juga didukung dengan data rata-rata selisih nilai pretes-postes siswa seperti yang terlihat pada Gambar 5.
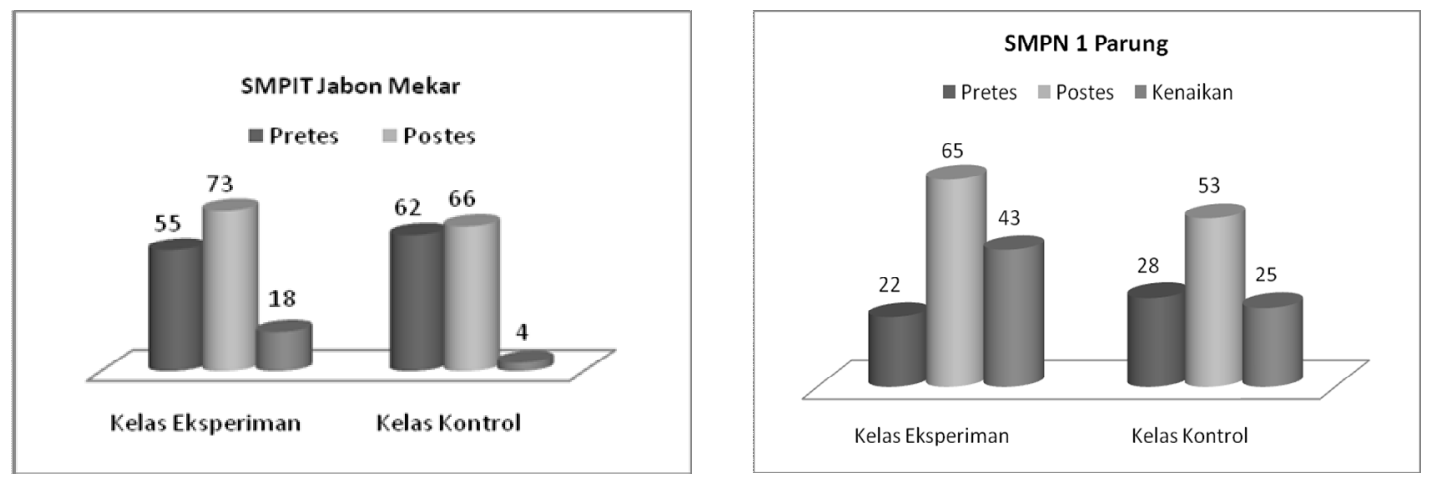

Gambar 5. Kenaikan nilai dari pretes ke postes 
Data di atas menunjukkan bahwa peningkatan kemampuan penalaran deduktif siswa yang diberi perlakuan pembelajaran model PMR lebih besar dibandingkan dengan siswa yang diberi perlakuan model konvensional. Selain itu peningkatan hasil postes lebih besar dibandingkan dengan hasil pretes. Peningkatan hasil postes pada kelas eksperimen lebih besar bila dibandingkan dengan hasil postes pada kelas kontrol.

Perbedaaan kemampuan penalaran deduktif, siswa yang diberi perlakuan model PMR dengan siswa yang diberi perlakuan model konvensional disebabkan oleh: (i) adanya konteks yang membuat siswa lebih fokus terhadap pelajaran matematika dan memudahkan siswa memahami pelajaran, (ii) adanya model dalam menyelesaikan masalah untuk memudahkan penyelesaian masalah tersebut dan berfungsi sebagai 'jembatan' menuju ke kegiatan matematisasi vertikal (kegiatan formal matematika), (iii) model PMR memberikan kesempatan yang luas kepada siswa untuk menemukan sendiri definisi atau aturan dalam matematika, (iv) adanya interaksi antara siswa dengan temannya sendiri, dengan guru maupun dengan lingkungannya yang memudahkan siswa merumuskan atau memahami suatu konsep, dan (v) keterkaitan antar topik dapat memudahkan siswa dalam memahami suatu konsep.

Hasil penelitian ini mirip dengan hasil penelitian Haji (2005) yang menunjukkan bahwa PMR mampu meningkatkan kemampuan pemecahan masalah siswa, dan penelitian Turmudi (2000) yang menunjukkan bahwa pendekatan realistik dalam pembelajaran matematika dapat mengubah minat siswa menjadi bersikap positif terhadap matematika.

\section{KESIMPULAN DAN SARAN}

Dampak model pembelajaran matematika realistik pada SMPIT Jabon Mekar dan SMPN 1 Parung adalah bahwa Model PMR dapat meningkatkan kemampuan penalaran deduktif siswa di SMPIT Jabon Mekar dan SMPN 1 Parung. Sedangkan persepsi guru dan siswa di SMPIT Jabon Mekar dan SMPN 1 Parung terhadap model pembelajaran matematika realistik adalah positif. Penerapan pembelajaran matematika menggunakan model PMR menjadi lebih menyenangkan dan siswa menjadi lebih aktif.

Karena itu, Model PMR perlu segera diterapkan dalam pembelajaran matematika untuk meningkatkan penalaran dedukif siswa serta menumbuhkan sikap siswa yang positif terhadap matematika. Selain itu, perlu dilakukan penelitian lebih lanjut tentang penerapan model PMR pada masalah dan subjek yang berbeda.

\section{REFERENSI}

De Lange, J. (1987). Mathematics, Insight and Meaning. Utrecht: OW \& CO.

Gravemeijer, K.P.E. (1994). Developing realistic mathematics education. Utrecht: Freudenthal Institute.

Haji, S. (2006). Meningkatkan kemampuan pemecahan masalah melalui pembelajaran matematika realistik di SMPN 1 Kota Bengkulu. Laporan Penelitian PTK Dikti. Bengkulu: Tidak diterbitkan.

Hamzah. (2003). Meningkatkan kemampuan memecahkan masalah matematika siswa sekolah lanjutan tingkat pertama negeri di Bandung melalui Pendekatan Pengajuan Masalah.

Bandung: Program Pascasarjana UPI Bandung. Tidak diterbitkan.

Marpaung, Y. (2004). Reformasi pendidikan matematika di sekolah dasar. Yogyakarta: Yayasan BP Basis. Majalah Basis: nomor 07-08.

Pannen, P. (2004). Pembelajaran kreatif berbasis seni lokal. Jakarta: FKIP Universitas Terbuka. 
Sabandar, J. (2001). Refleksi dalam pembelajaran matematika realistik. Makalah seminar nasional tentang Pendidikan matematika realistik Indonesia, 14-15 November 2001. Universitas Sanata Dharma Yogyakarta.

Soejadi, R. (2000). Kiat pendidikan matematika di Indonesia. Konstatasi keadaan masa kini menuju harapan masa depan. Jakarta: Direktorat Jenderal Pendidikan Tinggi. Departemen Pendidikan Nasional.

Suriasumantri, J. (1998). Filsafat ilmu sebuah pengantar populer. Jakarta: Sinar Harapan.

Turmudi. (2000). Peningkatan kemampuan pemahaman konsep matematika bagi siswa SLTP melalui pendekatan realistik. Laporan Hasil Penelitian Hibah-DUE-Like, Universitas Pendidikan Indonesia.

Zulkardi. (2003). RME Suatu inovasi dalam pendidikan matematika di Indonesia (Suatu pemikiran Pasca Konferensi Matematika Nasional 17-20 Juli). Makalah. 